\title{
KONDUKTIVITAS TERMAL PASIR KALI SEBAGAI MEDIA PENGHANTAR PANAS PADA PROSES PENYANGRAIAN KERUPUK
}

\section{Thermal Conductivity Of River Sand As A Heat Transfer Medium In The Cracker Roasting Process}

\author{
Lina Nirwana'), Muh. Rais'2), Jamaluddin P3) \\ 1)Mahasiswa Program Studi Pendidikan Teknologi Pertanian FT UNM, \\ 2) dan ${ }^{3)}$ Dosen FT UNM \\ linanirwana2@gmail.com
}

\begin{abstract}
ABSTRAK
Tujuan dari penelitian ini adalah untuk mengetahui konduktivitas panas pasir sungai dengan diameter yang berbeda sebagai media perpindahan panas pada proses penyangraian kerupuk. Penelitian ini merupakan penelitian eksperimen dengan menggunakan dua jenis diameter pasir yaitu pasir berdiameter besar dan pasir diameter kecil pada tiga (3) variasi suhu 120,140 dan $160^{\circ} \mathrm{C}$, dan empat (4) variasi lama pemanggangan adalah $10,15,20$ dan 25 detik. Selama proses penyangraian dilakukan pengukuran suhu pada pasir dan kerupuk, perhitungan nilai konduktivitas termal pasir dan pengukuran kadar air. Hasil penelitian menunjukkan bahwa diameter pasir yang lebih kecil menyebabkan perpindahan panas lebih cepat sehingga nilai konduktivitas termal lebih tinggi. Semakin tinggi suhu dan proses pemanggangan yang lebih lama menggunakan pasir kecil menyebabkan perpindahan panas lebih cepat sehingga penguapan kadar air di dalam kerupuk lebih besar. Semakin tinggi nilai konduktivitas termal pasir, maka perpindahan panas semakin baik.

Kata Kunci : Penyangraian, Perpindahan panas, konduktivitas Termal, Pasir, Kadar air, Kerupuk
\end{abstract}

\begin{abstract}
The aims of this research was to determine the heat conductivity of river sand with different diameters as a heat transfer medium in the crackers roasting process. This research is experiment research using two types of sand diameter is big diameter sand and small diameter sand at three (3) temperature variations of 120, 140 and $1600^{\circ} \mathrm{C}$, and four (4) variations long of roasting is 10, 15, 20 and 25 seconds. During the roasting process do temperature measuremen on the sand and crackers, calculating the value of thermal conductivity of the sand and measurement of moisture content. The results showed that the smaller diameter of the sand cause heat transfer the faster so thermal conductivity value higher. The higher the temperature and the longer roasting process using small sand cause the heat transfer faster so the evaporation of water content in the crackers is greater. The higher the thermal conductivity value of the sand, so heat transfer is getting better.
\end{abstract}

\section{Keywords: Roasting, Heat transfer, Thermal conductivity, Sand, Water content, Crackers.}

\section{PENDAHULUAN}

Kerupuk merupakan produk makanan kering yang populer telah lama dikenal masyarakat Indonesia. Konsumsi kerupuk biasanya bukan hanya sebagai makanan utama melainkan sebagai 
makanan kecil, makanan ringan atau sebagai pelengkap hidangan yang umumnya dikonsumsi dalam jumlah kecil. Kerupuk yang beredar di pasaran terbuat dari tepung terigu dan tepung tapioka yang diberi bumbu-bumbu dan digoreng.

Pada umumnya, sebelum dikonsumsi kerupuk terlebih dahulu digoreng menggunakan minyak sehingga untuk penyimpanan kerupuk pada suhu ruang akan menyebabkan terjadinya perubahan pada kerupuk yang diakibatkan penyesuaian terhadap kondisi lingkungan. Perubahan yang sangat nyata adalah ketengikan yang diakibatkan oleh proses oksidasi lemak. Adanya masalah ketengikan ini akan berdampak perubahan bau dan cita rasa yang tidak diinginkan oleh konsumen. Selain ketengikan penyimpanan yang salah pada kerupuk akan menyebabkan penyerapan uap air, khususnya pada lingkungan yang memiliki tingkat kelembaban yang tinggi sehingga menyebabkan kerupuk mengalami penurunan kerenyahan atau melempem (Nurhayati, 2007).

Penggorengan merupakan proses pemasakan yang unik, menarik, dan banyak ragam makanan yang dimasak dengan cara tersebut. Ditinjau dari segi waktu proses, penggorengan adalah salah satu cara pemasakan produk pangan yang dilakukan secara cepat, dan cara ini dianggap paling efisien proses transfer panasnya ke produk pangan yang dimasak. Sebagai salah satu proses pemasakan, penggorengan tidak hanya dilakukan pada skala rumah tangga, tetapi juga dijumpai dalam industri pengolahan pangan baik industri berskala kecil maupun industri pangan berskala menengah.

Pada umumnya penggorengan dilakukan dengan menggunakan minyak yang berfungsi sebagai media penghantar panas, meratakan suhu, dan berperan sebagai pemberi rasa gurih. Selama penggorengan produk mengalami penyerapan minyak yang cukup tinggi, untuk kerupuk sebagai produk yang digoreng penyerapan minyak mencapai $18 \%$ sedangkan pada penggorengan bahan berpati penyerapan minyak mencapai $15 \%$ (Supriyanto, 2007). Penyerapan minyak yang cukup tinggi akan menyebabkan produk mudah menjadi tengik apabila selama penyimpanan terjadi kontak dengan oksigen. Kualitas produk yang jelek tampak kurang menarik, rasa yang kurang enak/gurih dan kemungkinan berbahaya bagi kesehatan apabila kandungan minyak terlalu tinggi dan dikonsumsi secara terus menerus (Supriyanto dkk., 2006).

Penggorengan merupakan salah satu aktivitas penting dan banyak dijumpai dalam industri pengolahan pangan, namun pada akhir-akhir ini banyak timbul kewaspadaan terhadap produk hasil gorengan yang menggunakan minyak, terutama minyak yang digunakan secara berulang. Pengkonsumsian minyak terutama lemak jenuh dianggap merupakan penyebab naiknya resiko sakit khususnya sakit jantung koroner, kanker, diabetes, dan tekanan darah tinggi (Sartika, 2009). Fakta permasalah tersebut memberikan pemikiran untuk dilakukan penelitian tentang penggorengan menggunakan pasir sebagai media penghantar panas, karena produk goreng pasir tidak mengandung minyak, serta pasir relatif mudah didapat dan murah.

Setiap material atau bahan seperti minyak, air, logam, besi, aluminium, tembaga, pasir dan lain-lain memiliki nilai konduktivitas panas yang berbeda-beda. 
Pasir adalah salah satu material berbentuk butiran-butiran berpori yang ketersediaannya sangat melimpah dan mudah diperoleh namun masih sangat kurang pemanfaatannya dalam bidang pertanian khususnya pangan, hal tersebut disebabkan karena kekurang cukupannya informasi mengenai kemampuan atau potensi yang ada pada pasir sebagai media yang dapat menghantarkan panas. Daya hantar panas suatu bahan sangat menentukan keefisienan dalam penyangraian bahan pangan, sehingga dalam pengolahan suatu bahan pangan sangat diperlukan adanya pengetahuan mengenai daya hantar panas media yang digunakan khususnya dalam proses penyangraian. Jenis-jenis pasir beraneka ragam bentuk, ukuran, warna dan tingkat kehalusannya, seperti pasir kali yang memiliki ukuran butiran yang berbeda, sehingga peneliti menduga dengan adanya perbedaan ukuran tersebut maka nilai konduktivitas panas atau daya hantar panasnya pun berbeda-beda.

Cara penyangraian dengan menggunakan pasir dalam proses transfer panasnya diduga lebih efisien karena luas kontak permukaan panas pasir cukup besar disamping itu pasir dengan wujud butiran (fluidized) yang disertai dengan pengadukan mempunyai sifat yang hampir sama dengan fluida (minyak) dalam hal menghantarkan panas selama penyangraian. Penggorengan dengan pasir luas kontak panasnya jauh lebih besar yaitu banyak terjadi melalui butiran pasir dengan diameter yang cukup kecil $\leq 2,00 \mathrm{~mm}$, sehingga transfer panas yang terjadi dengan cara ini akan lebih efisien (Siswantoro dkk., 2011). Untuk menghindari hasil pembakaran yang tidak sempurna karena tidak meratanya temperature pada ruang bakar adalah dengan menggunakan partikel yang berpori seperti pasir sehingga terjadi keseragaman temperature (Winaya, 2008).

Penggorengan makanan berpati (kerupuk) dengan pasir sebagai media penghantar panas telah dilakukan di beberapa daerah di Indonesia. Namun sejauh ini belum banyak informasi dan penelitian tentang penggorengan dengan pasir, terutama yang terkait dengan daya hantar panas (k) pasir dari permukaan penggorengan hingga pada produk yang akan digoreng. Menurut Jamaluddin, $\mathrm{H}$. Syam dan Kadirman (2016) pasir memiliki luas kontak panas yang besar karena berupa butiran yang berdiameter tidak lebih dari 2,00 mm. Berdasarkan hal tersebut maka peneliti menduga diameter pasir mempengaruhi daya hantar panas selama penyangraian, sehingga dapat menentukan suhu dan waktu serta jenis pasir yang tepat dalam proses penyangraian. Dengan pemahaman yang baik tentang fenomena penyangraian (tanpa minyak) diharapkan dapat digunakan dalam pengembangan teknologi penggorengan atau penyangraian. Sehingga dalam penelitian ini peneliti hanya mengamati daya hantar panas $(k)$ pasir kali dengan berbagai jenis ukuran butiran pasir pada proses penyangraian hingga diperoleh hasil penyangraian menggunakan pasir sebagai media penghantar panas yang terbaik, selain itu perhitungan kadar air juga dilakukan untuk melihat perubahan kadar air kerupuk.

\section{TUJUAN PENELITIAN}

Untuk mengetahui konduktivitas termal atau daya hantar panas pasir kali dengan diameter yang berbeda sebagai media penghantar panas pada proses penyangraian kerupuk dan untuk 
mengetahui perubahan kadar air kerupuk setelah proses penyangraian.

\section{METODE PENELITIAN}

Penelitian ini merupakan penelitian kuantitatif dengan pendekatan eksperimen yang terdiri atas 2 faktor. Faktor $\mathrm{A}$ adalah suhu dengan 3 taraf faktor $(120,140 \text { dan } 160)^{\circ} \mathrm{C}$, faktor B adalah lama penyangraian dengan taraf faktor $(10,15,20$ dan 25) detik. Dengan demikian banyaknya perlakuan yang akan dicobakan sebanyak 24 kombinasi perlakuan. Setiap kombinasi perlakuan diulang sebanyak 3 kali.

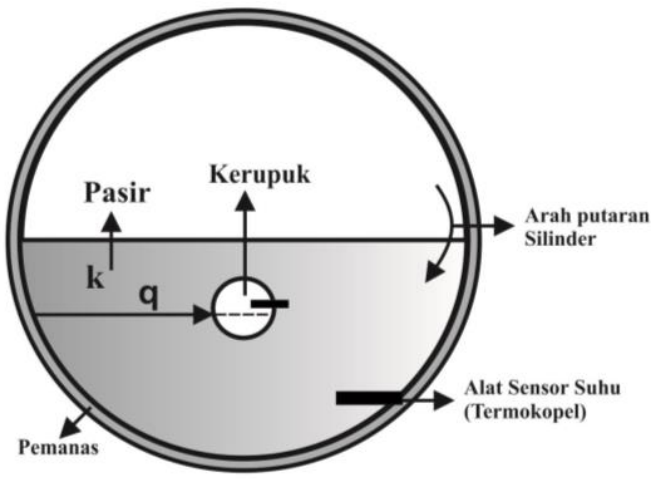

Gambar 1.

Sketsa Proses Penyangraian dengan Pasir sebagai Media Penghantar Panas

Penelitian ini akan dilakukan penyangraian kerupuk dengan pasir sebagai media penghantar panas menggunakan mesin penyangrai dengan sumber panas dari kompor gas. Pasir yang digunakan dalam penelitian ini adalah pasir kali dengan diameter yang berbeda yaitu berdiameter 0,6-1,2 dan 1,2-2 mm, kerupuk yang digunakan dalam penelitian ini memiliki ukuran diameter 2,5 cm dengan ketebalan 1,5 $\mathrm{mm}$. penyangraian kerupuk dilakukan menggunakan variasi suhu dan lama penyangraian, untuk variasi suhu terdiri dari 3 yaitu 120,140 dan $160^{\circ} \mathrm{C}$, sedangkan untuk lama penyangraian terdiri dari 4 yaitu $10,15,20$ dan 25 detik.

Alat-alat yang digunakan dalam penelitian ini meliputi, mesin penyangrai ( $p=32 \mathrm{~cm}, d=22 \mathrm{~cm}, r p m=35)$, kompor gas, alat pengukur suhu terdiri dari sensor suhu (termokopel), alat pengumpul data (NI-Cdaq 9174), stopwatch, komputer, ayakan pasir (mesh 8, 10, 16 dan 18) timbangan analitik, oven, desikator, tofles dan kemasan plastik.

Bahan-bahan yang digunakan dalam penelitian ini yaitu pasir kali berdiameter \pm 1 dan $\pm 2 \mathrm{~mm}$ yang diperoleh dari sungai je'neberang pinggir tanggul Desa Taeng Dusun Gantarang kab. Gowa, kerupuk cap udang dan gas LPG $12 \mathrm{Kg}$.

Penelitian ini akan dilaksanakan di Laboratorium Pendidikan Teknologi Pertanian Fakultas Teknik Universitas Negeri Makassar pada bulan Maret 2017 sampai dengan Juli 2017.

\section{HASIL DAN PEMBAHASAN}

\section{Konduktivitas Termal}

\section{Perubahan Suhu Pasir Sebelum Penyangraian}

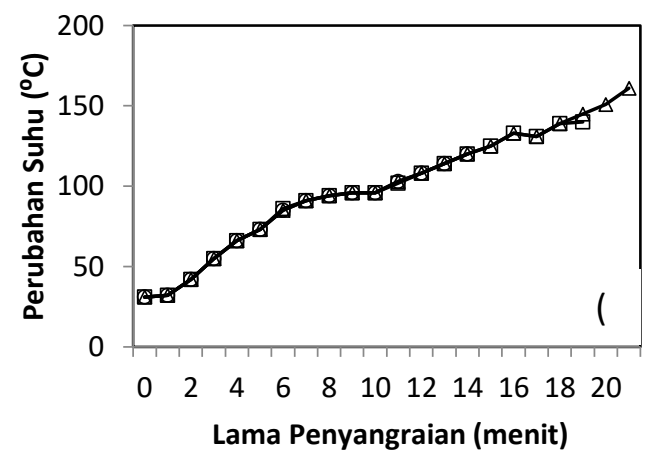




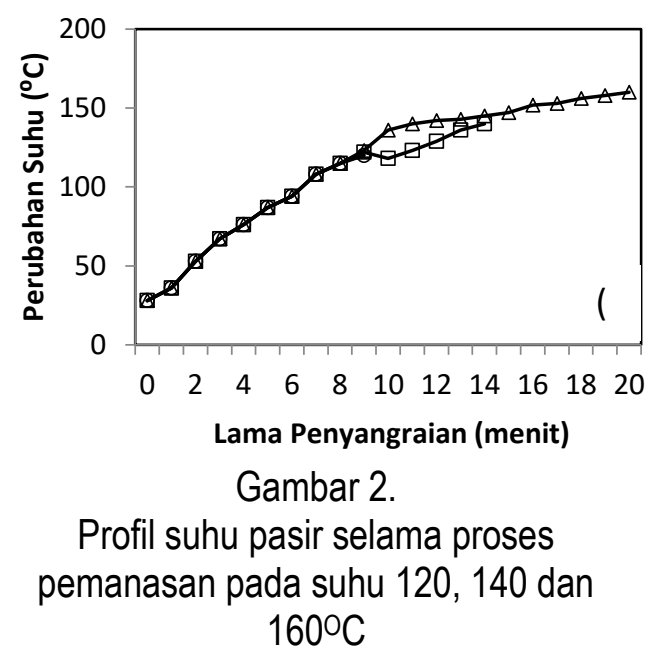

(a) pasir diameter besar $(1,2-2 \mathrm{~mm})$ dan (b) pasir diameter kecil $(0,6-$ $1,2 \mathrm{~mm})$.

Keterangan :

$$
\begin{aligned}
& \circ=\text { Temperatur Pasir } 120^{\circ} \mathrm{C} \\
& \square=\text { Temperatur Pasir } 140^{\circ} \mathrm{C} \\
& \Delta=\text { Temperatur Pasir } 160^{\circ} \mathrm{C}
\end{aligned}
$$

Hasil penelitian menunjukkan adanya peningkatan suhu secara bertahap dari waktu ke waktu hingga mencapai suhu yang ditelah di tetapkan, untuk mencapai suhu $120^{\circ} \mathrm{C}$ membutuhkan waktu yang lebih singkat dibandingkan waktu untuk mencapai suhu $140^{\circ} \mathrm{C}$ dan untuk mencapai suhu $160^{\circ} \mathrm{C}$ membutuhkan waktu yang relatif lebih lama. Untuk kedua jenis pasir terjadi perbedaan lamanya waktu pencapaian suhu pada pasir diameter besar dan pasir diameter kecil. Pasir diameter besar membutuhkan waktu selama 14, 19, dan 20 menit untuk mencapai suhu 120,140 , dan $160^{\circ} \mathrm{C}$, sedangkan pasir diameter kecil membutuhkan waktu yang lebih singkat untuk mencapai suhu 120, 140, dan $160^{\circ} \mathrm{C}$ yaitu selama 9,14 , dan 20 menit.

Pemanasan pasir dilakukan terlebih dahulu sebelum proses penyangraian, dimana suhu pasir yang akan dicapai sebesar 120, 140, dan $160^{\circ} \mathrm{C}$ dengan menggunakan termokopel sebagai alat pengukur suhu. Hasil penelitian pengukuran suhu pasir selama pemanasan menunjukkan adanya peningkatan suhu dari waktu ke waktu secara bertahap hingga mencapai suhu yang telah ditetapkan. Hal ini disebabkan karena adanya perbedaan suhu yang mengakibatkan terjadinya proses pindah panas dari api ke penggorengan selanjutnya ke pasir melalui proses hantaran panas konduksi, seperti yang dikemukakan oleh Pratiwi (2009) bahwa perpindahan panas terjadi karena adanya perbedaan suhu pada suatu bahan, sehingga terjadi perpindahan energi dari bagian bersuhu tinggi ke bagian yang bersuhu rendah, perpindahan energi tersebut disebabkan adanya molekul yang mengangkut energi ke bagian yang suhunya lebih rendah. Selain itu peningkatan suhu yang terjadi juga disebabkan karena suhu pasir yang belum digunakanan untuk menyangrai kerupuk sehingga belum ada transfer panas antara pasir dan kerupuk. Sejalan dengan pendapat Siswantoro, dkk. (2012) yang menyatakan bahwa selama penggorengan panas yang ditransfer dari pasir ke dalam bahan (kerupuk) selain digunakan untuk menaikkan suhu kerupuk juga digunakan untuk penguapan air bahan.

Lama pemanasan suhu $120^{\circ} \mathrm{C}$ membutuhkan waktu yang lebih singkat dibandingkan lama pemanasan pada suhu $140{ }^{\circ} \mathrm{C}$ dan lama pemanasan pada suhu $160^{\circ} \mathrm{C}$ membutuhkan waktu yang relatif lebih lama. Semakin rendah suhu yang akan dicapai maka waktu yang dibutuhkan akan semakin singkat dan sebaliknya semakin besar suhu yang ingin dicapai maka waktu yang digunakan juga semakin lama.

Untuk kedua jenis pasir terjadi perbedaan lamanya waktu pencapaian suhu pada pasir diameter besar dan 
pasir diameter kecil. Pasir diameter besar membutuhkan waktu selama 14 , 19, dan 20 menit untuk mencapai suhu 120,140 , dan $160^{\circ} \mathrm{C}$, sedangkan pasir diameter kecil membutuhkan waktu yang lebih singkat untuk mencapai suhu 120 , 140 , dan $160^{\circ} \mathrm{C}$ yaitu selama 9,14 , dan 20 menit. Hal ini disebabkan karena adanya perbedaaan diameter pasir yang mempengaruhi kerapatan tumpukan pasir, dimana pasir yang memiliki diameter lebih besar akan membutuhkan waktu pemanasan yang cukup lama dibandingkan pasir berdiameter kecil, karena udara panas yang melewati pasir diameter besar lebih lama perambatannya untuk melakukan kontak dengan butiran-butiran pasir lainnya disebabkan ukuran butiran pasir yang besar sehingga kerapatan tumpukan pasir agak renggang, semakin besar diameter pasir maka kandungan udara di dalam tumpukan pasir akan semakin besar (Siswantoro dkk., 2008).

Berbeda halnya dengan pasir berdiameter kecil, dimana semakin kecil diameter pasir maka kerapatan tumpukannya semakin rapat sehingga kandungan udara di dalam tumpukan pasir akan semakin kecil, akibatnya perambatan udara panas semakin cepat kontak dengan butiran pasir lainnya. Menurut Jamaluddin, H. Syam dan Kadirman (2015) pasir merupakan benda padat yang berbentuk butiran, pada kondisi tumpukan (bulk) pasir merupakan benda yang bersifat porus. Perambatan panas pada benda yang bersifat porus (seperti pasir) lebih kompleks dari pada perambatan panas yang terjadi pada benda padat yang non-porus (Baver (1961) dalam Jamaluddin, H. Syam dan Kadirman, 2015).

\section{Perubahan Suhu Pasir Dan Kerupuk Selama Proses Penyangraian}
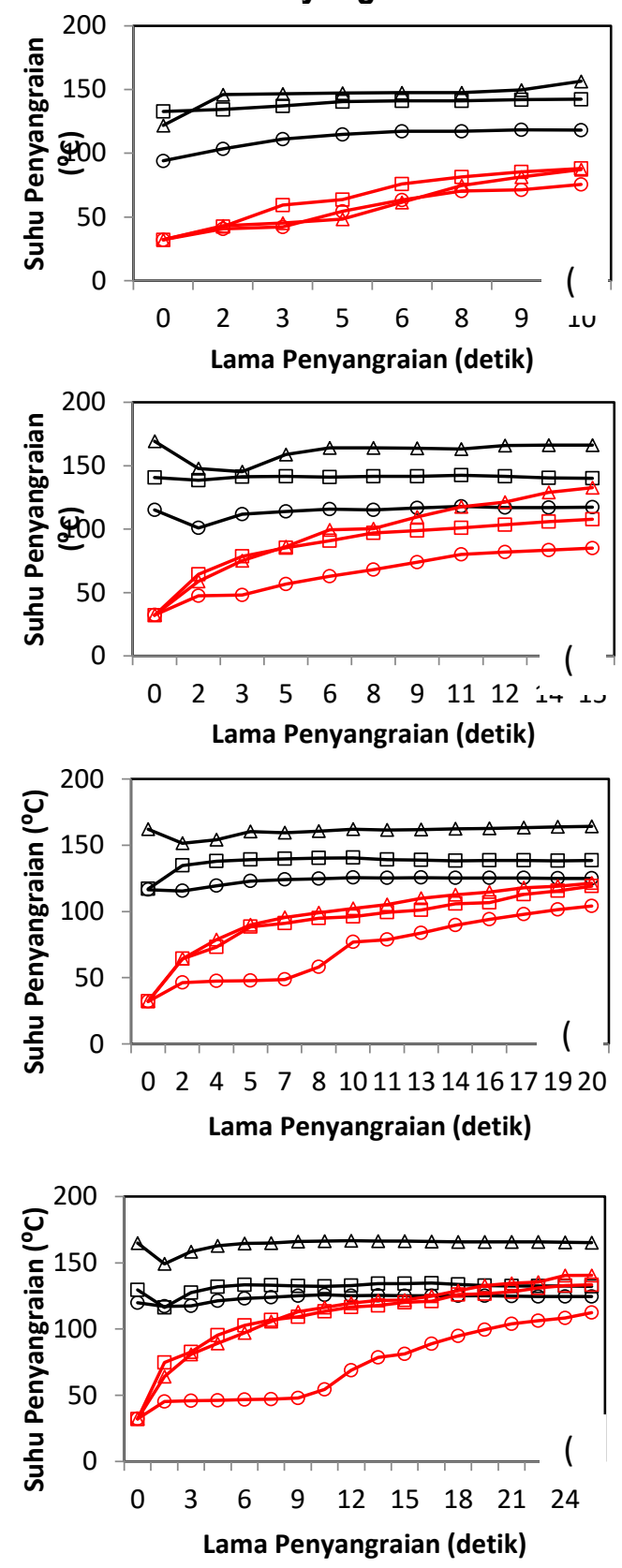

Gambar 3.

Temperatur pasir (TP) dan kerupuk (TK) selama proses penyangraian menggunakan pasir diameter besar (1,2-

$2 \mathrm{~mm}$ ) pada masing-masing suhu sebesar 120,140 , dan $160^{\circ} \mathrm{C}$ selama (a) 10 detik, (b) 15 detik, (c) 20 detik dan (d) 25 detik. 
Keterangan :

$\mathrm{o}=$ Temperatur Pasir $120^{\circ} \mathrm{C}$

$\square=$ Temperatur Pasir $140^{\circ} \mathrm{C}$

$\Delta=$ Temperatur Pasir $160^{\circ} \mathrm{C}$

$\mathrm{o}=$ Temperatur Kerupuk $120^{\circ} \mathrm{C}$

$\square=$ Temperatur Kerupuk $1400^{\circ} \mathrm{C}$

$\Delta=$ Temperatur Kerupuk $160^{\circ} \mathrm{C}$

Hasil penelitian menunjukkan bahwa pada proses penyangraian kerupuk menggunakan pasir diameter besar selama 10 detik terjadi peningkatan suhu yang signifikan disemua perlakuan suhu baik suhu pasir maupun suhu kerupuk. Proses penyangraian kerupuk selama 15 detik terjadi penurunan suhu pasir diawal penyangraian kemudian terjadi peningkatan suhu dan penurunan kembali atau perubahan suhu pasir yang tidak konstan, namun pada suhu kerupuk mengalami peningkatan suhu yang signifikan.

Proses penyangraian kerupuk selama 20 detik mengalami perubahan suhu pasir yang berbeda, pada suhu 120 dan $140^{\circ} \mathrm{C}$ suhu pasir diawal pemanasan cenderung mengalami peningkatan, dan pada pemanasan selanjutnya mengalami penurunan dan konstan, sedangkan pada suhu $160^{\circ} \mathrm{C}$ mengalami penurunan suhu di awal penyangraian, dan pada waktu penyangraian selanjutnya mengalami peningkatan suhu yang signifikan. Suhu kerupuk di awal penyangraian pada suhu $120^{\circ} \mathrm{C}$ mengalami peningkatan yang relatif lambat kemudian di waktu penyangraian selanjutnya terjadi peningkatan suhu yang cepat. Berbeda dengan suhu kerupuk pada penyangraian suhu 140 dan $160^{\circ} \mathrm{C}$, pada awal penyangraian, suhu kerupuk mengalami peningkatan yang cepat kemudian melambat.
Proses penyangraian selama 25 detik mengalami perubahan suhu pasir yang tidak konstan di awal penyangraian dan penurunan suhu di akhir penyangraian, sedangkan suhu kerupuk pada suhu penynagraian $120^{\circ} \mathrm{C}$ mengalami peningkatan suhu yang relatif lambat di awal penyangraian kemudian terjadi peningkatan suhu yang sangat cepat di detik penyangraian selanjutnya hingga akhir penyangraian peningkatan suhu mulai lambat. Sedangkan suhu kerupuk pada suhu penyangraian 140 dan $160^{\circ} \mathrm{C}$ mengalami peningkatan suhu yang sangat cepat di detik awal penyangraian, kemudian terjadi peningkatan suhu yang lambat di detik penyangraian selanjutnya hingga akhir penyangraian.
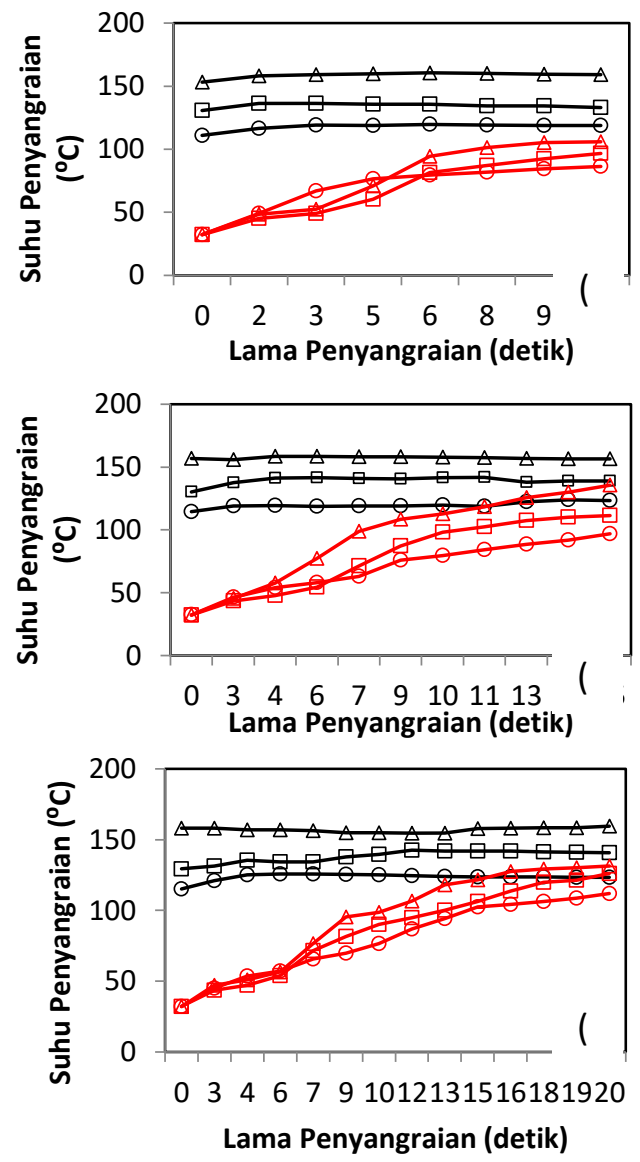


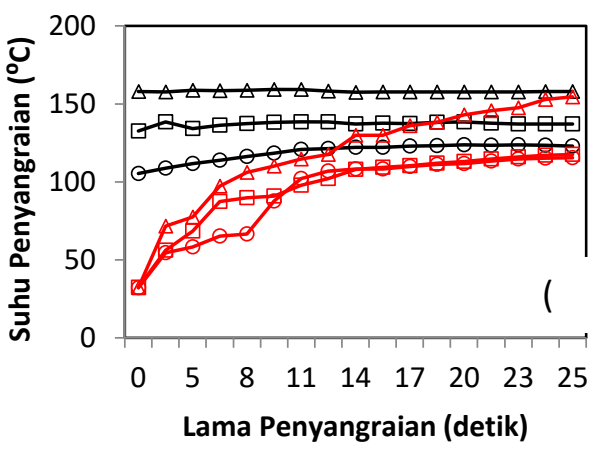

Gambar 4.

Temperatur pasir (TP) dan kerupuk (TK) selama proses penyangraian menggunakan pasir diameter kecil (0,60-

$1,2 \mathrm{~mm}$ ) pada masing-masing suhu sebesar 120,140 , dan $160^{\circ} \mathrm{C}$ selama (a) 10 detik, (b) 15 detik, (c) 20 detik dan (d) 25 detik.

Keterangan :

$\mathrm{O}=$ Temperatur Pasir $120^{\circ} \mathrm{C}$

$\square=$ Temperatur Pasir $140^{\circ} \mathrm{C}$

$\Delta=$ Temperatur Pasir $160^{\circ} \mathrm{C}$

$\mathrm{O}=$ Temperatur Kerupuk $120^{\circ} \mathrm{C}$

$\square=$ Temperatur Kerupuk $140^{\circ} \mathrm{C}$

$\Delta=$ Temperatur Kerupuk $160^{\circ} \mathrm{C}$

Hasil peneliian menunjukkan bahwa pada proses penyangraian kerupuk menggunakan pasir diameter kecil selama 10 detik terjadi peningkatan suhu pasir di awal penyangraian kemudian pada detik penyangraian selanjutnya suhu pasir mengalami penurunan hingga akhir penyangraian. Suhu kerupuk mengalami peningkatan yang cepat diawal penyangraian kemudian pada detik penyangraian selanjutnya suhu kerupuk mengalami peningkatan yang relatif lambat hingga mendekati konstan.

Proses penyangraian kerupuk selama 15 detik pada suhu penyangraian $120{ }^{\circ} \mathrm{C}$ terjadi peningkatan suhu pasir yang signifikan dari waktu ke waktu, sedangkan pada suhu penyangraian 140 dan $160^{\circ} \mathrm{C}$ terjadi peningkatan suhu pasir di awal penyangraian kemudian pada detik penyangraian selanjutnya suhu pasir mengalami penurunan hingga akhir penyangraian dan konstan. Selama proses penyangraian suhu kerupuk mengalami peningkatan yang cepat di tahap awal penyangraian kemudian mulai melambat di akhir penyangraian.

Proses penyangraian kerupuk selama 20 detik mengalami perubahan suhu yang tidak konstan atau terjadinya peningkatan dan penurunan suhu hingga akhir penyangraian. Beda halnya dengan suhu kerupuk yang mengalami kenaikan suhu dengan cepat di awal proses penyangraian dan selanjutnya peningkatan suhu mulai melambat dan mendekati konstan di akhir penyangraian.

Proses penyangraian selama 25 detik mengalami perubahan suhu pasir yang tidak konstan di awal penyangraian dan penurunan suhu di akhir penyangraian hingga konstan, sedangkan suhu kerupuk pada suhu penyangraian 120 dan $140^{\circ} \mathrm{C}$ mengalami peningkatan suhu yang relatif cepat di awal penyangraian selanjutnya menuju akhir penyangraian peningkatan suhu mulai lambat dan akhirnya konstan di akhir penyangraian. Sedangkan suhu kerupuk pada suhu penyangraian $160^{\circ} \mathrm{C}$ mengalami peningkatan suhu yang sangat cepat di awal penyangraian, kemudian terjadi peningkatan suhu yang mulai lambat di detik penyangraian selanjutnya, hingga pada akhir penyangraian suhu kerupuk konstan dan mendekati suhu pasir.

Berdasarkan gambar 3 dan 4 menunjukkan adanya transformasi suhu pada suhu penyangraian 120,140 , dan $160^{\circ} \mathrm{C}$ sehingga terjadi perubahan suhu pasir dan kerupuk selama proses penyangraian, perubahan suhu pada pasir diameter besar dan pasir diameter kecil relatif tidak konstan atau tidak tetap 
karena panas yang ada pada pasir digunakan untuk proses pemanasan dalam meningkatkan suhu kerupuk dan menguapkan kadar air, sedangkan suhu pada kerupuk relatif meningkat secara signifikan dari waktu ke waktu hingga konstan pada waktu tertentu. Peningkatan suhu kerupuk selama proses penyangraian disebabkan karena adanya proses transfer panas dari media penghantar panas yaitu pasir ke kerupuk. Peristiwa berpindahnya kalor atau panas dari suatu tempat ke tempat lain sebagai akibat perbedaan suhu disebut perpindahan kalor (Paubun dkk., 2009).

Perambatan panas antara pasir diameter besar dan pasir diameter kecil ke kerupuk terdapat perbedaan, dimana perambatan panas pasir diameter besar ke kerupuk lebih lambat dibandingkan perambatan panas dari pasir diameter kecil ke kerupuk, hal tersebut disebabkan karena ukuran diameter butiran pasir yang mempengaruhi kerapatan tumpukan pasir sehingga kecepatan perambatan panas pada pasir diameter kecil lebih cepat karena luas permukaan kontak panasnya semakin besar. Semakin kecil ukuran diameter pasir yang digunakan maka nilai kontak panas permukaan (h) akan semakin besar (Siswantoro, R. Ediati dan R. Listanti. 2014).

Lamanya waktu dan besaranya suhu yang digunakan dalam proses penyangraian juga mempengaruhi transfer panas dari pasir ke kerupuk, semakin lama waktu penyangraian dan semakin besar suhu yang digunakan maka panas yang ditransfer ke kerupuk juga semakin besar, sehingga suhu kerupuk semakin meningkat.

Perambatan panas dari media penghantar panas ke bahan terjadi secara bertahap atau mengalami 3 fase perambatan panas yaitu pada awal proses peyangraian suhu pasir mengalami penurunan dan suhu kerupuk mengalami peningkatan yang cepat karena pada tahap ini terjadi kontak langsung media pasir dan kerupuk yang disangrai sehingga panas yang ada pada pasir digunakan untuk meningkatkan suhu kerupuk. Pada proses penyangraian tahap selanjutnya peningkatan suhu cenderung melambat karena pada tahap ini panas akan masuk ke dalam bahan yang disangrai untuk menguapkan kadar air yang ada dipermukaan dan di dalam kerupuk. Pada tahap akhir proses penyangraian peningkatan suhu cenderung konstan dan suhu kerupuk mendekati suhu pasir karena pada tahap ini merupakan proses pemasakan bahan atau kerupuk yang di sangrai dimana panas yang ada pada pasir tidak lagi untuk menguapkan kadar air namun digunakan untuk proses pemasakan kerupuk. Perpindahan panas dari permukaan bahan ke dalam bahan berlangsung secara konduksi, dimana energi molekul langsung berubah dari daerah yang lebih panas ke daerah yang lebih dingin, molekul dengan energi yang lebih besar memindahkna sebagian energi ke molekul sekitarnya yang mempunyai energi yang lebih kecil (Jamaluddin, H. Syam dan Kadirman, 2016). 
Nilai Konduktivitas Termal

Tabel 1

Nilai konduktivitas termal pasir diameter besar $(1,2-2 \mathrm{~mm})$

\begin{tabular}{cccc}
\hline $\begin{array}{c}\text { Lama } \\
\text { Penyangrai }\end{array}$ & \multicolumn{3}{c}{$\begin{array}{c}\text { Konduktiitas Termal } \\
\text { an (detik) }\end{array}$} \\
\cline { 2 - 4 } a $\mathrm{C})$ \\
\cline { 2 - 4 } & $\begin{array}{c}\text { Suhu Penyangraian }\left({ }^{\circ} \mathrm{C}\right) \\
120\end{array}$ & 140 & 160 \\
$\mathbf{1 0}$ & 17.24 & 17.24 & 17.24 \\
$\mathbf{1 5}$ & 17.24 & 17.24 & 17.24 \\
$\mathbf{2 0}$ & 17.24 & 17.24 & 17.24 \\
$\mathbf{2 5}$ & 17.24 & 17.24 & 17.24 \\
\hline
\end{tabular}

Tabel 2

Nilai konduktivitas termal pasir diameter kecil $(0,6-1,2 \mathrm{~mm})$

\begin{tabular}{|c|c|c|c|}
\hline \multirow{3}{*}{$\begin{array}{c}\text { Lama } \\
\text { Penyangrai } \\
\text { an (detik) }\end{array}$} & \multicolumn{3}{|c|}{$\begin{array}{c}\text { Konduktiitas Termal } \\
\left(\mathrm{W} / \mathrm{m} .{ }^{\circ} \mathrm{C}\right)\end{array}$} \\
\hline & \multicolumn{3}{|c|}{ Suhu Penyangraian $\left({ }^{\circ} \mathrm{C}\right)$} \\
\hline & 120 & 140 & 160 \\
\hline 10 & 18.81 & 18.8 & 18.81 \\
\hline 15 & 18.81 & 18.8 & 18.81 \\
\hline 20 & 18.81 & 18.81 & 18.81 \\
\hline 25 & 18.81 & 18.81 & 18.81 \\
\hline
\end{tabular}

Berdasarkan data pada Tabel 1 dan 2 menunjukkan nilai konduktivitas termal pasir yang sama besar pada berbagai variasi waktu dan suhu penyangraian, namun nilai konduktivitas termal kedua jenis pasir berbeda, dimana nilai konduktivitas termal pasir kecil lebih besar yaitu $18,81 \mathrm{~W} / \mathrm{m} .{ }^{\circ} \mathrm{C}$ dengan diameter pasir 0,6-1,2 mm dibanding nilai konduktivitas panas pasir besar yaitu $17,24 \mathrm{~W} / \mathrm{m} .{ }^{\circ} \mathrm{C}$ dengan diameter pasir 1,2-2 $\mathrm{mm}$.

Konduktivitas termal merupakan kemampuan suatu benda dalam menghantarkan panas. Konduktivitas panas merupakan properti dari suatu material yang menentukan kemampuan suatu benda menghantarkan panas.
Materi yang memiliki konduktivitas panas rendah dapat disebut dengan isolator yang baik (Falcon, 2008).

Cara penggorengan dengan menggunakan pasir (hot sand frying) proses transfer panasnya diduga lebih efisien dibanding cara penyangraian karena luas kontak permukaan panas pasir cukup besar disamping itu pasir dengan wujud butiran (fluidized) yang disertai dengan pengadukan mempunyai sifat yang hampir sama dengan fluida (minyak) dalam hal menghantarkan panas selama penggorengan (Siswantoro, R. Ediati dan R. Listanti, 2014)

Hasil analisa perhitungan konduktivitas termal pada pasir menunjukkan bahwa adanya perbedaan nilai konduktivitas pasir diameter besar dan pasir diameter kecil. Perbedaan perlakuan suhu dan lama penyangraian memberikan nilai konduktivitas termal pada pasir diameter besar sama besar yaitu sebesar $17 \mathrm{~W} / \mathrm{m} .{ }^{\circ} \mathrm{C}$, sama halnya pada pasir diameter kecil, suhu dan lama penyangraian tidak memberi pengaruh terhadap nilai konduktivitas termal sehingga semua perlakuan memiliki nilai konduktivitas termal yang sama besar yaitu sebesar $18 \mathrm{~W} / \mathrm{m} .{ }^{\circ} \mathrm{C}$.

Nilai konduktivitas pasir diameter kecil lebih besar dibandingkan nilai konduktivitas pasir diameter besar, ini sejalan dengan penelitian yang dilakukan oleh Siswantoro, dkk. (2012) bahwa makin tinggi rpm maka intensitas kontak akan makin besar, demikian juga dengan makin kecil ukuran diameter pasir, maka luas permukaan kontak antara pasir dengan produk yang digoreng akan makin besar. Hal tersebut disebabkan karena ukuran diameter butiran pasir yang berbeda sehingga mempengaruhi kerapatan tumpukan pasir akibatnya proses perambatan panas pada pasir 
diameter kecil lebih cepat sehingga nilai konduktivitasnya lebih besar.

Penggorengan dengan pasir luas kontak panasnya jauh lebih besar yaitu banyak terjadi melalui butiran pasir dengan diameter yang cukup kecil $\leq$ 2,00 $\mathrm{mm}$, sehingga transfer panas yang terjadi dengan cara ini akan lebih efisien (Siswantoro dkk., 2011). Semakin kecil diameter butiran pasir maka semakin cepat perambatan panasnya sehingga perubahan suhu disekelilingnya semakin cepat, ini menunjukkan bahwa semakin cepat perambatan panasnya maka nilai konduktivitasnya semakin besar. Hal ini sejalan dengan pendapat yang dikemukakan oleh Sarifuddin dan R. Ekafitri (2015) bahwa nilai konduktivitas termal yang tinggi menunjukkan bahwa material tersebut lebih cepat mengalami perubahan suhu jika terdapat gradient suhu disekelilingnya. Beberapa hasil penelitian menerangkan bahwa makin besar diameter partikel (d) yang mengalir disekitar bahan, maka akan menyebabkan nilai koefisien kontak panas permukaan makin menurun, sedangkan makin besar aliran media disekitar bahan maka nilai koefisien kontak panas permukaan akan makin besar (Masoumifard dkk. (2008) dalam Siswantoro dkk. 2012). Nilai konduktivitas termal pasir tidak menunjukkan adanya perbedaan pada tiap perlakuan suhu dan lama penyangraian, hal ini disebabkan karena nilai konduktivitas termal pasir merupakan besaran intensif suatu bahan yang menunjukkan ketetapan kemampuannya untuk menghantarkan panas, sehingga nilai $k$ pada pasir diameter besar sama begitupula pada pasir diameter kecil.
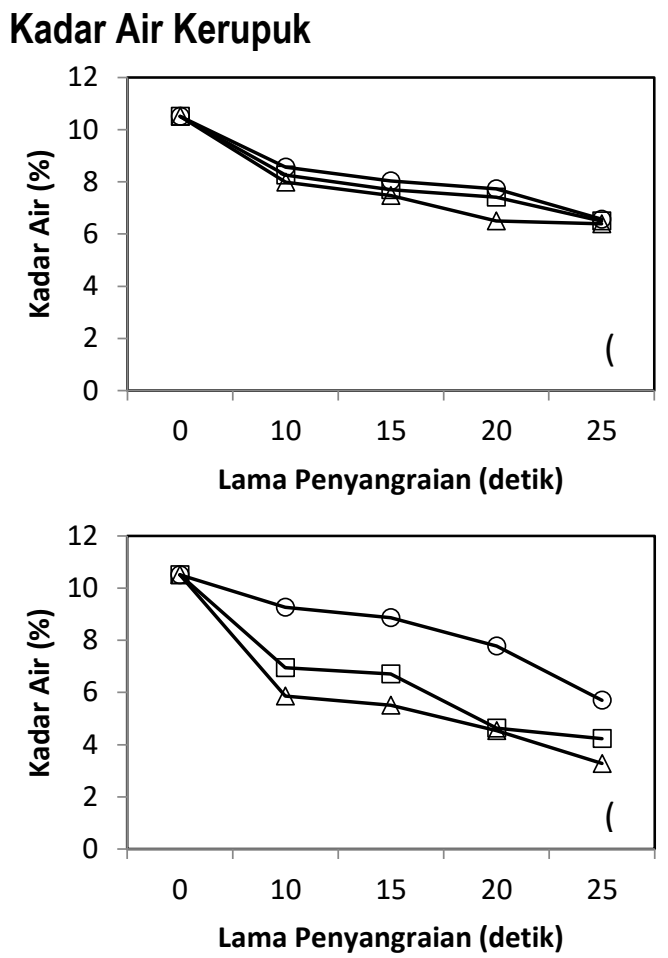

Gambar 5

Kadar air kerupuk pada proses penyangraian pada suhu 120,140 , dan $160^{\circ} \mathrm{C}$ selama $10,15,20$ dan 25 detik menggunakan (a) pasir diameter besar (1,2-2 mm) dan (b) pasir diameter kecil (0,6-1,2 mm).

Keterangan :

$$
\begin{aligned}
& \mathrm{O}=\text { Temperatur } 120^{\circ} \mathrm{C} \\
& \square=\text { Temperatur } 140^{\circ} \mathrm{C} \\
& \Delta=\text { Temperatur } 160^{\circ} \mathrm{C}
\end{aligned}
$$

Hasil penelitian menunjukkan perubahan kadar air selama proses penyangraian, kerupuk yang disangrai menggunakan pasir diameter besar menunjukkan penurunan kadar air yang tidak jauh berbeda, sedangkan kadar air kerupuk yang disangrai menggunakan pasir diameter kecil menunjukkan penurunan kadar air yang lebih besar antar perlakuan waktu dan suhu penyangraian.

Kadar air merupakan salah satu sifat kimia dari bahan yang menunjukkan jumlah persentase air yang terkandung 
di dalam bahan pangan (Riansyah, 2013). Hasil analisa perhitungan kadar air kerupuk menunjukkan bahwa perlakuan suhu dan lama penyangraian yang berbeda pada proses penyangraian menggunakan pasir diameter besar dan pasir diameter kecil menunjukkan adanya perbedaan kadar air kerupuk setelah proses penyangraian. Kadar air kerupuk sebelum penyangraian sebesar $10,51 \%$, setelah proses penyangraian menggunakan pasir diameter besar kadar air kerupuk semakin menurun. Kerupuk dengan persentase kadar air tertinggi diperoleh dari perlakuan suhu $120^{\circ} \mathrm{C}$ selama 10 detik yaitu sebesar $8,56 \%$, penurunan kadar air setelah penyangraian sebesar 1,95\%. Kadar air terendah diperoleh dari perlakuan suhu $160{ }^{\circ} \mathrm{C}$ selama 25 detik yaitu sebesar $6,39 \%$, penurunan kadar air sebesar $4,12 \%$.

Proses penyangraian kerupuk menggunakan pasir diameter kecil mengalami penurunan kadar air, kerupuk dengan persentase kadar air tertinggi yaitu pada perlakuan suhu $120^{\circ} \mathrm{C}$ selama 10 detik sebesar 9,26\%, penurunan kadar air setelah penyangraian sebesar $1,25 \%$. Kadar air terendah diperoleh dari perlakuan $160^{\circ} \mathrm{C}$ selama 25 detik yaitu sebesar $3,28 \%$, penurunan kadar air sebesar $7,23 \%$. Persentase kadar air kerupuk terkecil yaitu sebesar 3,28\% yang diperoleh dari penyangraian menggunakan pasir diameter kecil pada suhu $160^{\circ} \mathrm{C}$ selama 25 detik. Penurunan kadar air pada perlakuan tersebut yang paling besar diantara perlakuan lainnya yaitu sebesar $7,23 \%$. Hal tersebut disebabkan karena penggorengan pada suhu tinggi dan tekanan hampa udara lebih rendah, perpindahan panas ke permukaan dan kemudian masuk ke dalam padatan lebih cepat dibanding pada suhu rendah dan tekanan hampa udara lebih tinggi, sehingga air di permukaan dan di dalam padatan lebih cepat keluar menyebabkan padatan menjadi menyusut dan beberapa lama menjadi mekar (Jamaluddin dkk., 2011).

Persentase penguapan kadar air terbesar terjadi pada penyangraian kerupuk menggunakan pasir diameter kecil pada suhu $160^{\circ} \mathrm{C}$ selama 25 detik. Hal tersebut disebabkan karena ukuran butiran diameter pasir yang kecil sehingga perambatan panas pada tumpukan pasir semakin cepat sampai ke permukaan bahan sehingga penguapan kadar air semakin cepat dan persentase kehilangan kadar air semakin besar. Pada tahap akhir proses penyangraian, peningkatan suhu kerupuk semakin konstan dan mendekati suhu pasir karena kadar air di dalam bahan semakin berkurang sehingga penguapan kadar air semakin kecil. Penyangraian kerupuk menggunakan pasir diameter besar menghasilkan penurunan persentase kadar air yang rendah karena ukuran butiran diameter pasir yang besar, sehingga perambatan panas dari pasir ke permukaan kerupuk semakin lambat. Penurunan persentase kadar air bahan yang rendah karena selain perambatan panas yang lambat juga lama waktu yang digunakan selama proses penyangraian terbatas, sehingga penguapan kadar air di dalam kerupuk tidak merata, hanya terjadi di permukaan kerupuk. Selama proses penyangraian menggunakan pasir diameter besar masih terjadi peningkatan suhu di dalam kerupuk karena masih terjadi proses penguapan kadar air sehingga tidak semua kadar air di dalam bahan teruapkan.

Penurunan kadar air yang rendah diawal proses penyangraian karena pada tahap ini terjadi kontak panas dari pasir 
ke permukaan bahan sehingga penguapan kadar air mula-mula terjadi di permukaan bahan yang berlangsung lebih cepat, dan pada tahap penyangraian selanjutnya penguapan kadar air terjadi di dalam bahan yang disebut sebagai penguapan lanjutan, pada tahap ini penguapan kadar air cenderung lambat karena jumlah kadar air bahan semakin berkurang sehingga penguapan kadar air menurun, sedangkan kadar air terbesar terdapat pada permukaan bahan. Pada akhir penyangraian penguapan kadar air semakin berkurang karena pada tahap ini terjadi proses pemasakan bahan dan suhu kerupuk cenderung konstan hingga mendekati suhu pasir, sehingga kadar air yang tersisa di dalam bahan tidak dapat teruapkan lagi. Hasil ini sesuai dengan penelitian Asensio (1999) serta Yamsaengsung et. al. (2002a) dalam Jamaluddin, dkk. (2009) yang menjelaskan bahwa perubahan bahan selama penggorengan disebabkan karena hilangnya air terikat dalam bahan. Pada awal penggorengan mulamula air bebas di permukaan keluar dan beberapa lama air bebas dalam padatan juga keluar mengakibatkan padatan menjadi menyusut. Setelah semua air bebas keluar terjadi pengerasan di permukaan sehingga sebagian air bebas terjebak di dalam padatan.

Semakin tinggi suhu dan semakin lama waktu yang digunakan pada proses penyangraian menyebabkan penguapan kadar air di dalam bahan semakin besar sehingga jumlah kadar air bahan semakin kecil. Hal ini disebabkan karena besarnya panas yang di transfer oleh pasir menyebabkan peningkatan suhu pada kerupuk, sehingga semakin tinggi suhu kerupuk maka penguapan kadar air semakin besar. Selama penggorengan panas yang ditransfer dari pasir ke dalam bahan (kerupuk) selain digunakan untuk menaikkan suhu kerupuk juga digunakan untuk penguapan air bahan (Siswantoro dkk., 2012).

\section{KESIMPULAN}

Berdasarkan hasil penelitian, maka dapat disimpulkan bahwa nilai konduktivitas termal pasir diameter besar dan pasir diameter kecil berbeda, hal tersebut disebabkan karena adanya perbedaan ukuran butiran diameter pasir yang mempengaruhi laju perambatan panas pada pasir. Semakin besar diameter pasir maka luas permukaan kontak panas antar bahan semakin menurun, perambatan panas pada tumpukan pasir semakin lambat sehingga nilai konduktivitas panas semakin rendah yaitu sebesar 17,24 $\mathrm{W} / \mathrm{m} .{ }^{\circ} \mathrm{C}$, sebaliknya semakin kecil diameter pasir maka luas permukaan kontak panas antar bahan semakin meningkat, perambatan panas pada tumpukan pasir semakin cepat sehingga nilai konduktivitas panas semakin tinggi yaitu sebesar $18,81 \mathrm{~W} / \mathrm{m} .{ }^{\circ} \mathrm{C}$. semakin tinggi nilai konduktivitas termal suatu bahan maka kemampuan suatu bahan dalam menghantarkan panas semakin baik.

Selama proses penyangraian panas yang ditransfer dari pasir ke dalam bahan (kerupuk) selain digunakan untuk menaikkan suhu kerupuk juga digunakan untuk penguapan air bahan. Semakin tinggi suhu dan semakin lama waktu penyangraian maka proses perpindahan panas semakin cepat dan penguapan kadar air di dalam bahan semakin besar.

\section{DAFTAR PUSTAKA}

Falcon, Rafael. 2008. Analisis Karakteristik Termal dan 
Resistansi Konduktor pada Kabel Inti Ganda NYM 2 × $1,5 \mathrm{~mm}^{2}$. Skripsi. Depok: Program Studi Teknik Elektro Universitas Indonesia.

Jamaluddin, Husain Syam dan Kadirman. 2015. Rekayasa Penyangraian, Perpindahan Panas dan Penguapan Air Secara Simultan, Serta perubahan Tekstur, Volume dan Warna pada Makanan Berpati. Penelitian Hibah Kompetensi. Teknologi Hasil Pertanian Universitas Negeri Makssar.

, Husain Syam dan Kadirman.

2016. Konduktivitas Panas Jenis Pasir Sebagai Media Penghantar Panas pada Proses Penyangraian Makanan Berpati. Fakultas Teknik, Uniersitas Negeri Makassar.

Suardy, Siswantoro dan S. Laga. 2011. Pengaruh Suhu dan Tekanan Vakum Terhadap Penguapan Air. Perubahan Volume dan Rasio Densitas Keripik Buah Selama dalam Penggorengan Vacum. Jurnal Teknologi Pertanian. Volume 12 (2). Halaman 100-108.

B. Rahardjo, P. Hastuti dan Rochmadi. 2009. Rekayasa Pemekaran dan Tekstur Keripik Buah Nangka Selama Penggorengan Vakum. Jurnal Keteknikan Pertanian. Volume 23 (2). Halaman 125-132.

Nurhayati, Ari. 2007. Sifat Kimia Kerupuk Goreng yang Diberi Penambahan Tepung Daging Sapi dan Perubahan Bilangan TBA Selama Penyimpanan. Skripsi. Bogor:
Program Studi Teknologi Hasil Ternak, Fakultas Peternakan, Institut Pertanian Bogor.

Paubun, N. Susana, R.A. Kadiwano, E.O.B. Kambe, Wahyu H.K dan Ferdy S. Rondonuwu. 2009. Konsepsi Mahasiswa Tentang Perpindahan Kalor. Prosiding Seminar Nasional Penelitian, Pendidikan dan MIPA. Yogyakarta: Fakultas MIPA Uniersitas Negeri Yogyakarta.

Pratiwi, Wening. 2009. Teknik Puffing Pemanasan Konduksi Granula Pasir Panas dalam Pembuatan Berondong Jagung Varietas Unggul Nasional. Skripsi. Bogor: Fakultas Teknologi Pertanian, Institut Pertanian Bogor.

Riansyah, Angga. 2013. Pengaruh Perbedaan Suhu dan Waktu Pengeringan Terhadap Karakteristik Ikan Asin Sepat Siam Menggunakan Oven. (Online), (http://repsitory.ugm.ac.id, diakses 22 Februari 2017).

Sarifudin, Achmat dan Riyanti Ekafitri. 2015. Karakteristik Sifat Fisiko Kimia dan Thermal Serta Penerimaan Organoleptik Kue Sagon Berbasis Tepung Pisang. Jurnal Penelitian Pasca Panen. Volume 12 (1). Halaman 27-37.

Sartika, Dewi R.A. 2009. Pengaruh Suhu dan Lama Proses Menggoreng (Deep Frying) Terhadap Pembentukan Asam Lemak Trans. Makara, Sains. 13: 23-28.

Siswantoro, B. Raharjo, N. Bintoro dan P. Hastuti. 2008. Model Matematik Transfer Panas Pada Penggorengan Menggunakan 
Pasir. Makalah. Disajikan pada Prosiding Seminar Nasional Teknik Pertanian yang diselenggarakan oleh Universitas Gadjah Mada. Yogyakarta. 18-19 November 2008.

B. Rahardjo, Nursigit Bintoro dan Pudji Hastuti. 2011. Pemodelan Matematik Perubahan Parameter Mutu Kerupuk Selama Penggorengan dengan Pasir. Jurnal Teknologi dan Industri Pangan. Volume 22 (1). Halaman 17-25.

B. Rahardjo, Nursigit Bintoro dan Pudji Hastuti. 2012. Pemodelan Matematik Pindah Panas dan Massa pada Penggorengan dengan Pasir sebagai Media Penghantar Panas. Agritech. 32 (1): 87-97.

R. Ediati dan Riana Listanti. 2014. Rancang Bangun Alat Penggoreng Tanpa Minyak untuk Menunjang Agroindustri. Agrin ISSN: 1410-0029. Volume 18 (2). Halaman 167-180.

Supriyanto. 2007. Proses Penggorengan Bahan Makanan Berpati: Kajian Nisbah Amilosa Amilopektin. Disertasi. Yogyakarta: Program Studi Teknik Pertanian Universitas Gadjah Mada.

Supriyanto, B. Rahardjo, Y. Marsono dan Supranto. 2006. Pemodelan Matematik Transfer Panas dan Massa pada Proses Penggorengan Bahan Makanan Berpati. Jurnal Teknologi dan Industri Pangan. Volume 17 (1). Halaman 28-37.

Winaya, I Nyoman S. 2008. Prospek Energi Dari Sekam Padi
Teknologi Fluidized Combustion. Majalah Inovasi Iptek, PPI Jepang. Volume 11 (20). Halaman 54. 